\title{
NEW TAXA AND COMBINATIONS IN EUCALYPTUS-4
}

\author{
L. A. S. Johnson AND D. F. BLAXELL
}

(Accepted 9.3.1978)

\section{ABSTRACT}

Johnson, L. A. S. (National Herbarium of New South Wales, Royal Botanic Gardens, Sydney, Australia 2000) and D. F. Blaxell (National Herbarium of New South Wales, Royal Botanic Gardens, Sydney, Australia 2000) 1980. New Taxa and Combinations in Eucalyptus -4. Telopea 1 (6): 395-397, Pl. XIV.-The new species E. olsenii from southern N.S.W. is described and a new series Olsenianae is set up within the subgenus Monocalyptus to accommodate it.

\section{MA.J: O Eucalyptus olsenii L. Johnson \& D. Blaxell, sp. nov.}

Arbor ad $10 \mathrm{~m}$ alta; cortex laevis. Cotyledones reniformes, discolores. Folia adulta lanceolata, non opposita, falcata, 6-14 cm longa, 1.5-2 cm lata. Nervi laterales non prominentes, sub angulo circa $35^{\circ}$. Umbellastri axillares, 7-florae. Alabastra matura circa $1.5 \mathrm{~cm}$ longa, perigynio campanulato, circa $1.0 \mathrm{~cm}$ longo, operculo conico, apiculato. Fructus globosi vel doliiformes, circa $1.5 \mathrm{~cm}$ diametro, valvis 4 in perigynio inclusis.

Holotype: Ridge S. of Dampier Trig., E. of Big Badja Hill, Southern Tablelands, New South Wales (MR 402100 Badja sheet 1:25000), H. Fairlie-Cuninghame NSW 132650, 6.1972 (NSW). PI. XIV. IsotyPES to be sent to K, FRI.

Tree to $10 \mathrm{~m}$ high, up to $0.3 \mathrm{~m}$ d.b.h. Bark smooth on trunk and branches, cream to whitish in colour, with a small stocking of rough (but not stringy) bark at the base. Cotyledons reniform, $0.8 \mathrm{~cm}$ long, $1.2 \mathrm{~cm}$ broad, green above, purplish beneath. Juvenile leaves opposite, ovate-lanceolate, sessile, paler beneath, c. $6 \mathrm{~cm}$ long, c. $2.5 \mathrm{~cm}$ wide, slightly cordate at the base. Leaves, stems and axillary shoots of young seedlings thickly clothed with radiating hairs of subtype "r (M)" (Johnson 1972). Adult leaves lanceolate, not opposite, petiolate, concolorous, up to $14 \mathrm{~cm}$ long and $2 \mathrm{~cm}$ wide. Lateral veins at c. $35^{\circ}$ to the midrib, not prominent, intramarginal vein c. $1 \mathrm{~mm}$ from the margin, not prominent. Petiole terete, slightly flattened dorsiventrally, c. $7 \mathrm{~mm}$ long. Umbellasters axillary, 7-flowered; peduncle terete to slightly flattened, 5-8 mm long, 3-4 mm in diameter. Mature buds sessile to slightly pedicellate c. $1.5 \mathrm{~cm}$ long; perigynium campanulate, c. $1 \mathrm{~cm}$ long, strongly ridged longitudinally but with two of the ridges more pronounced. Operculum single, conical to pyramidal, slightly apiculate, with two prominent longitudinal ridges continuous with those on the perigynium. Stamens pale yellow, all fertile; filaments flexuose, of various lengths, not all sharply deflexed in the bud; anthers reniform, c. $0.5 \mathrm{~mm} \times 0.5 \mathrm{~mm}$. Style thick, c. $1 \mathrm{~mm}$ in diameter, reaching almost to inner tip of operculum in bud. Fruits globular to barrel-shaped, c. $1.5 \mathrm{~cm}$ in diameter, sessile, longitudinally ridged with two opposite ridges more pronounced particularly towards the base. Disc c. $4 \mathrm{~mm}$ wide, vertically depressed; staminophore narrow and, with the operculum scar, forming the rim of the orifice. Orifice c. $7 \mathrm{~mm}$ diameter. Valves 4 , deeply enclosed in the perigynium.

Distribution: This very distinct species is known only from a few localities in the same general area of the Southern Tablelands of New South Wales. Although we have not seen this species in the field, we understand that it forms almost pure stands on the tops and sides of steep rocky ridges (I. Olsen, H. Fairlie-Cuninghame \& M. I. H. Brooker pers. comm.) It is perhaps of interest that a new species of Acacia occurs associated with the eucalypt. 


\section{Plate XIV}

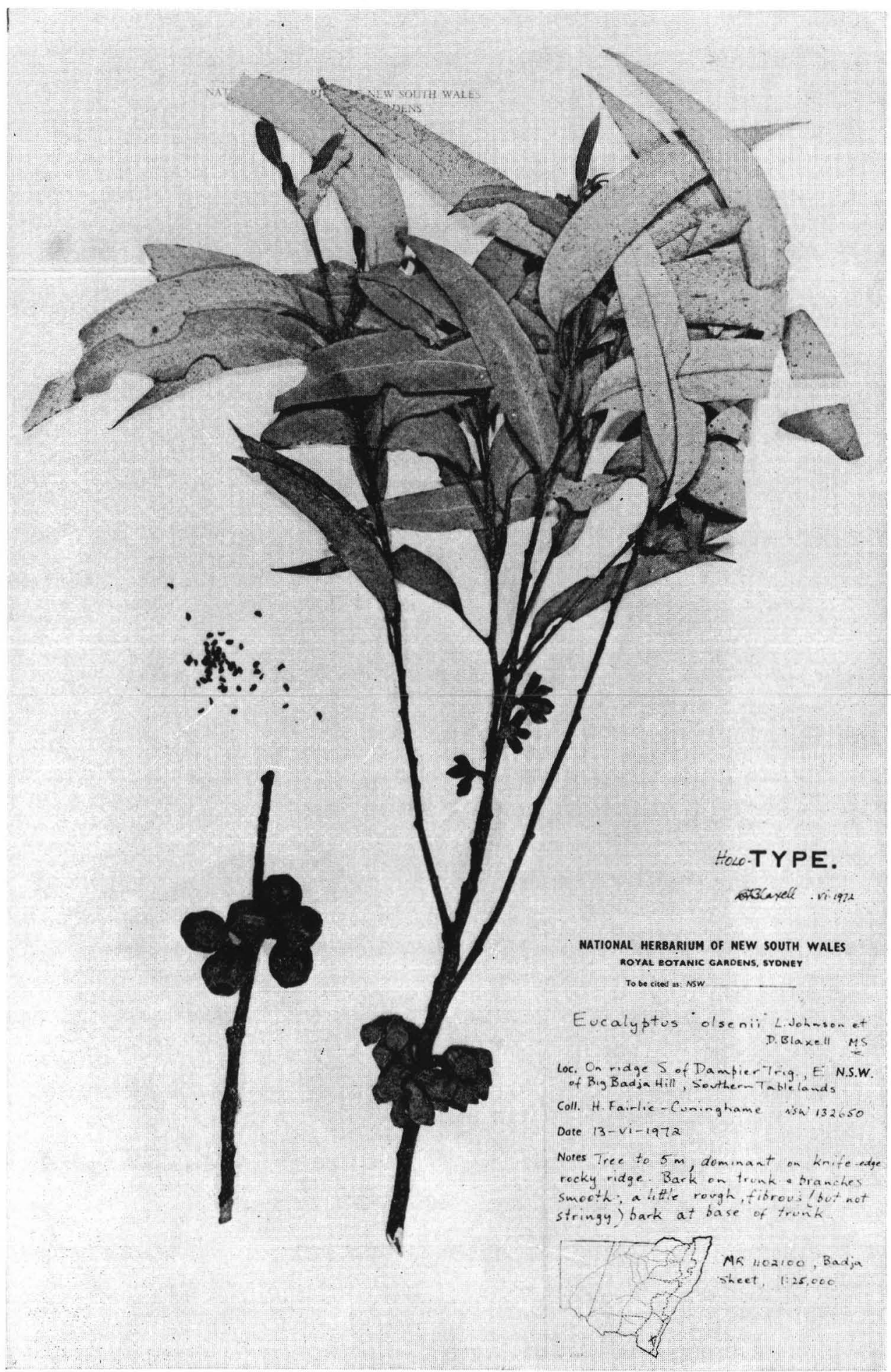

HoLOTYPE of Eucalyptus olsenii L. Johnson \& D. Blaxell 
SPECIMENS Examined: Mother Woila, Upper Tuross River area, I. Olsen 4.1971 (NSW); Ridge south of Dampier Trig., east of Big Badja Hill, H. Fairlie-Cuninghame NSW 132650, 6.1972 (NSW)-TYPE; Mother Woila, c. $72 \mathrm{~km}$ SSW. of Braidwood, $R$. G. Coveny 5945 \& A. N. Rodd 1.1975 (NSW); Mother Woila Peak, headwaters of Tuross River, $45 \mathrm{~km}$ NNW of Cobargo, R. Story 8198, 11.1975 (CA.NB, NSW).

This species has been named after Ian Olsen, formerly Landscape Designer at the Royal Botanic Gardens, Sydney, who has been responsible for bringing to our attention over a number of years many previously unknown taxa in several genera.

The affinities of this species are obscure. Initially we placed it near the "Ashes" (MAKI Strictinae) on the basis of leaf and fruit characters. When the first seedlings grown from the Olsen specimen were observed to have radiating hairs, we assumed that seed batches had been confused. More seeds from the same specimen were sown and the same seedling characters appeared. Hairs of subtype "r (M)" are a consistent feature of, and otherwise confined to, Series MAH Capitellatae, all members of which when mature have long-fibred bark of the "Stringybark" type. $E$. olsenii is essentially smooth-barked throughout and shows no indication of "stringy" bark even in the basal stocking. In fruit shape it somewhat resembles members of MAK Obliquae, especially subseries Strictinae.

Although it exhibits characters of both MAH Capitellatae and MAK Obliquae, we have erected the series MAJ Olsenianae to accommodate this very distinctive species. The groupings and coding in Monocalyptis will need to be altered in a future revision of the Pryor \& Johnson classification, and for the present E. olsenii is tentatively placed.

Analysis of the volatile oils of leaf material produced an unexpected mixture of components, of great interest to the chemists, but indicating no particular relationship of this species to any other in the subgenus (E. Lassak \& I. Southwell pers. comm.).

The authors wish to thank Ian Olsen for presenting them with an interesting and "non-conforming" taxon, and Henry Fairlie-Cuninghame who collected the Type material whilst leading a bushwalking party. We are also grateful to Erik Lassak and Ian Southwell of the Museum of Applied Arts and Sciences, Ultimo, for their co-operation in distilling and analysing the volatile oil from this new species.

\section{LITERATURE CITED}

Johnson, L. A. S., (1972)-Evolution and classification in Eucalyptus. Proc. Linn. Soc. New South Wales 97, 11-29.

Pryor, L. D. \& Johnson, L. A. S., (1971)-A Classification of the Eucalypts. Australian National University Press, Canberra. 